\title{
POSSIBILITIES OF GIS APPLICATION IN THE ORGANIZATION AND PRESENTATION OF TOURISM POTENTIALS - CASE STUDY OF SARAJEVO
}

DOI: http://dx.doi.org/10.18509/GBP.2015.16

UDC: 007:004]:528:338.483(497.6)

\author{
Dr. Sc. Nusret Dreskovic, assistant professor \\ Amra Banda, MA, teaching assistant, PhD student \\ Edin Hrelja, MA, senior teaching assistant, PhD student \\ Amina Sivac, BA, teaching assistant \\ University of Sarajevo, Faculty of Science, Department of Geography - Bosnia and Herzegovina
}

\begin{abstract}
Identification of tourism potential represents the initial step in the organization of tourism offer of the certain administrative units or other spatial units. Modern scientific concept of tourism motives identification implies their systematization at the level of adequate thematic geodata sets that are based on two conceptual models. First methodological concept involves identifying and inventorying tourism motives according to the components of physical geographic and social geographic environment. In this case, attributes of associated thematic geodatabase minimally include name, type, degree of attractiveness, photo and forms of tourism that can be developed in the analyzed site. Second methodological concept is based on the identification of the tourism potentials according to territorial principle, which involves formation of geodatabases for all forms of tourism motives and all forms of tourism that can be formed in defined destinations. The implementation of these methods should be the basis for an exact segregation of tourism geographical regions on mezo-regional and macro-regional level.
\end{abstract}

Keywords: identification, tourism potentials, attributes of geodatabases, tourismgeographical regions

\section{INTRODUCTION}

Bosnia and Herzegovina is a country with natural diversity and a rich cultural and historical heritage which has always been a real and very good basis for development of tourism. In the area of natural diversity, Bosnia and Herzegovina is among the European countries with highly developed physical geographic biodiversity and natural landscapes, especially in mountain areas. Movable and immovable cultural and historical heritage of Bosnia and Herzegovina and its individual regions is also extremely varied and reflects the very dynamic historical-geographical processes and changes that were taking place in certain periods of its development. Beside them, very characteristic are different ethnoevents and many other cultural events that significantly enrich the tourist offer.

However, main contemporary economic indicators of economic development indicate that the post-war strategy to intensify tourism development of Bosnia and Herzegovina to year 2013 was realized in a small scale of $2.5 \%$ of total GDP. According to this data 
the total revenue of Bosnia and Herzegovina in tourism was 670.4 million BAM. [1] According to the Agency for Statistics of Bosnia and Herzegovina total gross income in the area of accommodation and services in 2013. was around 260 million BAM with a total gross income in respect of accommodation amounted to about 151.5 million BAM. Individual administrative units among which Sarajevo Canton have different share in the registered structure of tourism economy in Bosnia and Herzegovina.

According to data of the Institute for Statistics of Federation of Bosnia and Herzegovina and the competent cantonal agencies, during 2014. 317,750 tourists visited Sarajevo Canton. In the arrivals structure in 2014. foreign tourists participated with about $83 \%$, while the arrivals to a specific destination of domestic tourists participate with a little more than $17 \%$. This ratio shows that the role of international tourists in the overall tourist economy is more significant and far exceeds the financial effects that generate domestic tourists. In the structure of international tourists the largest number of arrivals in the Sarajevo Canton is registered from Croatia, Turkey, Slovenia, Serbia and Germany. [2]

\section{OVERVIEW OF TOURIST POTENTIAL OF SARAJEVO CANTON}

In accordance to the given data for Bosnia and Herzegovina, it can be concluded that Sarajevo Canton has an exceptional natural-geographical and socio-geographical potential for development of virtually all forms of tourism, which enables the duration of the tourist season throughout the year.

\section{NATURAL HERITAGE OF SARAJEVO CANTON}

In the field of natural heritage, Sarajevo Canton has a continuous natural areas with distinctive values of natural diversity. Natural heritage also includes elements of individual natural monuments which have multiple natural heritage character. Biodiversity of Sarajevo Canton is also extremely diversed, with variety of plant and animal species and a large number of communities which are endemic for Bosnia and Herzegovina, such as Bosnian Lily (Lilium bosniacum), Bosnian Hawksbeard (Crepis bosniaca), Bosnian Iris (Iris bosniaca), Bosnian Orchis (Orchis bosniaca), Viola Elegantula (Viola elegantula), Dinaric Gentian (Gentiana dinarica), Sarajevo Widow Flower (Knautia sarajevoensis), Serbian Pancicia (Pancicia serbica) and many other.

Faunistic diversity of the Sarajevo Canton is also highly developed. The 54 (sub) species from 36 genera and 13 families belong to ichthyofauna diversity of Sarajevo Canton. In this area endangered species of relatively large schools (20-30 individuals) of Seagull (Larus ridibundus) and Little egret (Egretta garzetta) are occurring. In the area of Igman and Bjelašnica 33 families and 71 species of birds were found. The diversity of mammal fauna is also extremely varied and the most important species include: Brown bear (Ursus arctos), Gray wolf (Canis lupus), European wild cat (Felis silvestris silvestris), Chamois (Rupicapra), Deer (Cervus elaphus), Fallow deer (Dama dama), Fox (Vulpes vulpes), Weasel (Mustela putorius), River otter (Lutra lutra), Badger (meles meles), Pine marten (Martes martes), Beech marten (Martes foina) and others. 
These elements of natural-geographical diversity are the basis for tourist valorization of natural heritage. Applied methodological concept of the valorization of tourist potentials consideres continuous natural areas as locations with the highest concentration of individual elements of natural-geographical and biological diversity. In this sense, two types of continuous natural areas were allocated in Sarajevo Canton: protected natural areas and natural areas with high natural diversity. In the area of Sarajevo Canton four protected areas were established and categorized in the last two decades, all in accordance to the International Union Conservation Nature - IUCN:

- PA ,Skakavac““

- PA „Vrelo Bosne“

- PA „Bijambare“

- PA „Trebević“
- nature monument (category III);

- nature monument (category III);

- protected landscape (category V);

- protected landscape (category V)

Total size of these three areas is $2.930,9$ hectares, which is about $2.7 \%$ of the total Canton area. Each of these areas has its own special specificity in the field of natural-geographical and biological diversity (Map 1).

In addition, the expressed values of natural diversity are located in the southern parts of Canton in the area of Igman and Bjelašnica, Trebević, Treskavica, and Jahorina, as well as the area of Ozren, Bukovik, Čemerska mountains and Crnoriječka plateau in the northern part. The establishment of a protected area of II Category - National Park in the spatial coverage of about $395 \mathrm{~km}^{2}$ is envisioned on wider area of Igman, Bjelašnica, Treskavica and Visočica. [4]

These continuous natural areas contain all positive tourist-motif assumptions for the organization and development of different forms of tourism such as excursions, recreational, health, sports and recreation, sports, mountaineering, alpine climbing, caving, scientific, educational, eco-tourism, adventure and many other. In relation to the length of the tourist season, tourist evaluation of the mentioned elements of the natural heritage of Sarajevo Canton is based on seasonal and year-round visitors. Seasonal tourism is related to the two main climatic seasons - summer and winter, and is based on the appropriate types of tourism. The year-round tourist season is predominantly based on the excursion, recreation, sports and recreation, health, hiking, educational and ecotourism. 


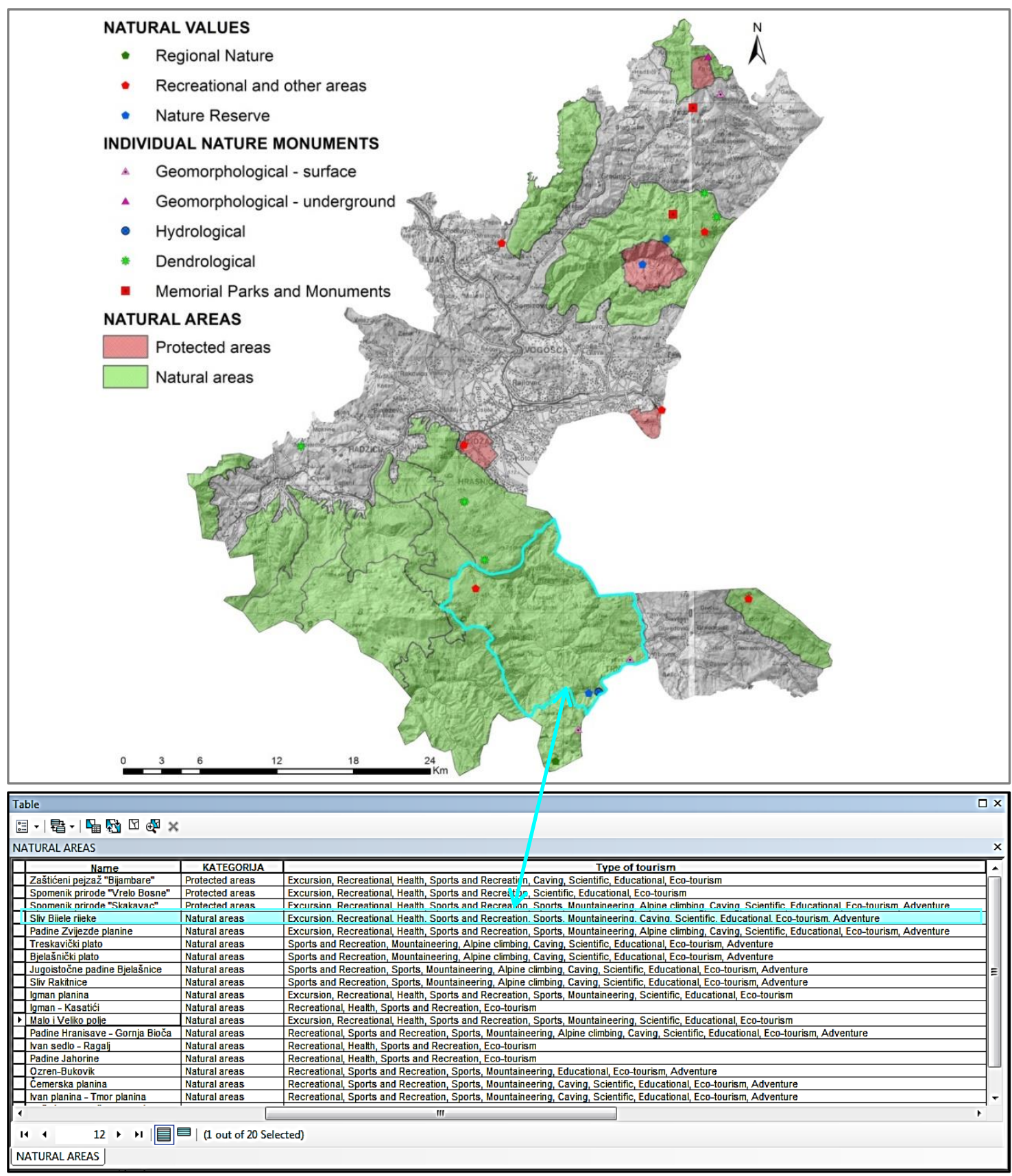

Fig. 1. GIS database of Sarajevo Canton's natural heritage with tourist information included

\section{CULTURAL-HISTORICAL HERITAGE OF SARAJEVO CANTON}

According to the Spatial plan of Sarajevo Canton for the period 2003 - 2023, culturalhistorical heritage of Canton is the sum of the architectural and natural heritage recorded and registered by the Cantonal Institute for the Protection of the Cultural and Natural Heritage. [3] Information on the cultural-historical heritage were supplemented by a significant document - Spatial plan of the Federation of Bosnia and Herzegovina for the period 2008-2028. 
Taking into account these and other used documents, in the Sarajevo Canton following categories of cultural-historical heritage can be subdivided:

- Historical and memorial complexes and facilities,

- Populated areas / units,

- Archaeological sites,

- Individual objects of architectural heritage,

- Fortifications and military architecture,

- Units of residential architecture,

- Public buildings,

- Economic buildings,

- Sacred objects

- Cemeteries.

In general it can be said that a large variety of cultural-historical heritage is not or is only partially adapted for tourist visits which is a deficiency in the organization of the overall tourism offer of the Sarajevo Canton. More specifically, according to the summary indicators in the area of Sarajevo Canton according to these categories of culturalhistorical heritage there are dozens of objects registered by the competent cantonal agencies (Table 1.)

Table 1. Summary indicators by category of cultural-historical heritage in the Sarajevo Canton.

\begin{tabular}{|c|l|c|c|c|c|}
\hline Nr. & \multicolumn{1}{|c|}{ Type of objects } & Total & Registered & Protected & Share (\%) \\
\hline 1 & $\begin{array}{l}\text { Historical and memorial complexes and } \\
\text { facilities }\end{array}$ & 81 & 63 & 18 & 22,2 \\
\hline 2 & Archaeological sites & 88 & 87 & 1 & 1,1 \\
\hline 3 & Populated areas / units & 141 & 76 & 65 & 46,1 \\
\hline 4 & $\begin{array}{l}\text { Individual objects (residential, public, } \\
\text { economic, military) }\end{array}$ & 292 & 236 & 56 & 19,2 \\
\hline 5 & Sacred objects & 109 & 82 & 27 & 24,8 \\
\hline 6 & Necropolis and cemeteries & 228 & 219 & 9 & 3,9 \\
\hline 7 & Natural heritage areas & 52078 ha & & 1804 ha & 1,42 \\
\hline
\end{tabular}



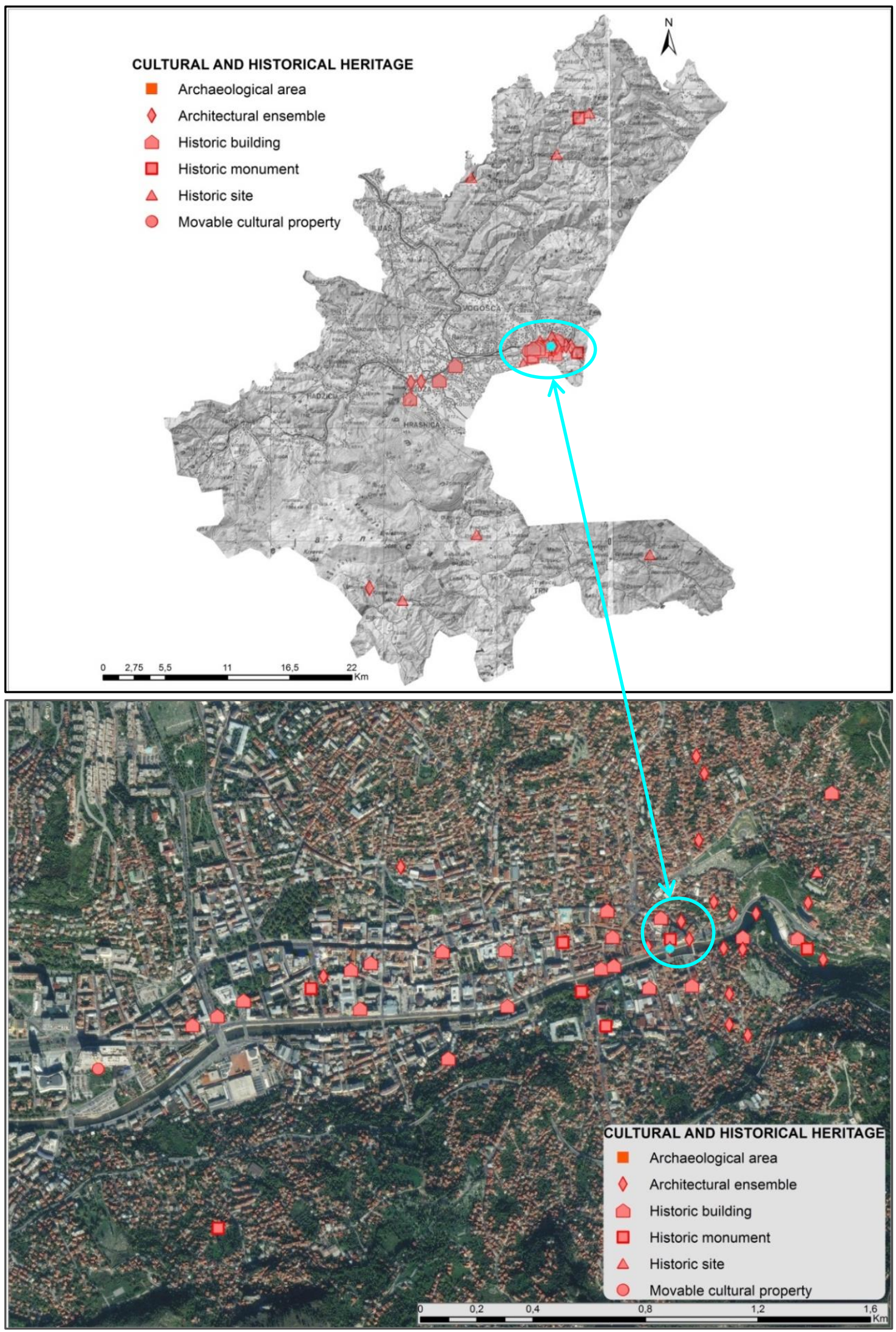


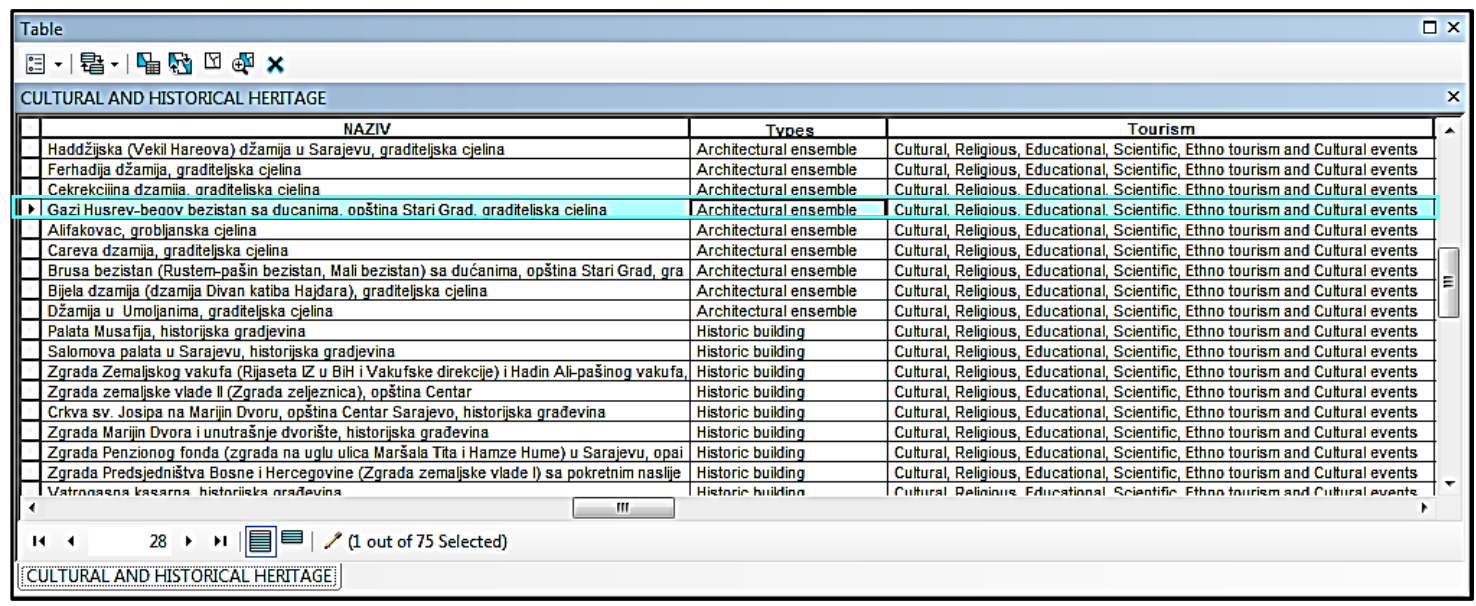

Fig. 2. GIS database of Sarajevo Canton's cultural-historical heritage with tourist information included

Great number of objects from the List of cultural-historical heritage is registered on the List of cultural-historical heritage as Objects of importance for the Federation of Bosnia and Herzegovina. Among the most important types of tourism that have been established on the basis of visits to the facilities and goods of cultural-historical heritage are: cultural, religious, educational, scientific, ethno tourism and tourism of cultural events. In general, it can be said that in the Sarajevo Canton there is a lot of intense tourist activity in terms of visits to the facilities and goods of cultural-historical heritage, including in particular objects of religious architecture such as: Gazi Husrev Bey's Careva's Mosque, Old Orthodox Church, Cathedral of the Sacred Heart etc. Among the most important contemporary cultural events in Sarajevo that particularly attract tourists from all over the Europe and round the world are Sarajevo Film Festival, MESS (Little experimental scenes Sarajevo) and Sarajevo Winter.

\section{CONCLUSION}

In relation to the capacity of tourist destinations for tourist visits Sarajevo Canton has a positive preconditions for the development of different forms of mass and special forms of tourism. Mass forms of tourism in Sarajevo Canton are mainly based on shorter visits of a large number of tourists during their free time, especially on weekends. Most often massively visited tourist destinations in Sarajevo Canton are located in mountainous areas, such as Igman, Bjelašnica, Visočica, part of Treskavica, part of Jahorina, Ozren, Bukovik and Crnoriječka plateau (Fig. 1). In this case, those are shorter stays of 1-3 days which generate tourists from the Sarajevo city and its wider region as well as tourists who come from countries from region: Slovenia, Croatia and Serbia. Main motives for mass stay of tourists in these destinations are vacation, recreational hiking and various sports and recreational activities in order to improve general health.

In addition to tourist offers based on shorter and more massive tourist visits, Sarajevo Canton has the potential for organizing additional tourist offer through various alternative forms of tourism, based on tourist services for certain small groups of tourists with specific requirements relating to the purpose and content of the arrival at a particular destination (Special Interest Tourism - SIT). It is common for this type of visit to be 
significantly more acceptable. The starting point for these forms of tourism is the transformation of developing tourist concept out of the growing volume of tourist visits where growth demand is based on a simple and inexpensive product which provides a great physical volume of tourist traffic in accordance to a diversification policy of tourist offer, where tourism products are adapted to the requirements of the few groups of tourists. More specifically, tourist offer is adapted to the specific requirements and expectations of smaller groups of tourist which are therefore financially more expensive and organizationally less demanding. SIT tourists focus of interest are specific motifs that stimulate these groups to travel, so development concept of the tourist offer in Canton's tourist destinations are directed to meet the desired needs of small number of tourists who are mainly homogeneous with respect to a particular expressed interest.

Accordingly, in the Sarajevo Canton following types of SIT tourism developed in physical-geographical tourist motives can be subdivided to: recreational, sightseeing, ecotourism, health, sports, rural (agro), hunting and fishing, hiking, adventure, Robinson and similar types of tourism. SIT Tourism in Sarajevo Canton based on socialgeographical motives differentiate the following types of tourism: congress (MICE meetings, incentives, conventions, events), cultural, gastronomic and oenologist, event tourism, religious, tourism on the artificial created attractions, casino and similar types of tourism.

\section{REFERENCES}

[1] Travel \& Tourism Economic Impact 2014 Bosnia and Herzegovina, World Travel \& Tourism Council (WTTC), United Kingdom, pp 1-6, 2014.

[2] Kanton Sarajevo u brojkama 2014, Institute for Statistics of Federation of Bosnia and Herzegovina, Bosnia and Herzegovina, pp 26-27, 2014.

[3] Spatial plan of Sarajevo Canton for the period 2003 - 2023, Institute for Planning of Sarajevo Canton Sarajevo, Bosnia and Herzegovina, pp 38-49, 2006.

[4] Spatial plan of Federation of Bosnia and Herzegovina for the period 2008.-2028., Federal Ministry of Physical Planning, Sarajevo, Bosnia and Herzegovina, pp 223-225 2012. 